\title{
HIV-Associated Malignant Lymphoma
}

\author{
Uta Brunnberg $^{\text {a }}$ Marcus Hentrich $^{b}$ Christian Hoffmann ${ }^{c, d}$ Timo Wolfa Kai Hübel ${ }^{e}$ \\ ${ }^{a}$ Department of Medicine II, University Hospital Frankfurt, Frankfurt/M., Germany; \\ ${ }^{b}$ Department of Medicine III, Red Cross Hospital Munich, Munich, Germany; \\ c ICH Study Center Hamburg, Hamburg, Germany; \\ dDepartment of Medicine II, University of Schleswig-Holstein, Campus Kiel, Kiel, Germany; \\ e Department of Medicine I, University Hospital Cologne, Cologne, Germany
}

\section{Keywords}

AIDS-related lymphoma, ARL · cART · Chemotherapy · Rituximab

\section{Summary}

Acquired immune deficiency syndrome (AIDS)-related lymphomas (ARL) still represent a relevant field of clinical research. For most histological subtypes of $A R L$, no optimal initial therapy has been clearly defined so far. Rituximab plus chemotherapy is feasible and effective and should be offered to all patients with CD20-positive ARL regardless of their CD4 cell count. Combination antiretroviral therapy (cART) should be given concomitantly with chemotherapy, bearing in mind potential drug-drug interactions. Appropriate treatment of ARL is determined by a number of factors such as lymphoma stage, performance status, comorbidities, histological subtype, and immunosuppression. Treatment should principally be the same as in human immunodeficiency virus (HIV)-negative lymphoma patients. In HIV-related Hodgkin's lymphoma, high cure rates have been achieved with stage-adapted treatment approaches, albeit with worse outcomes compared to immunocompetent patients.

(c) 2017 S. Karger GmbH, Freiburg

\section{Introduction}

People living with human immunodeficiency virus (HIV) have an increased relative risk of developing non-Hodgkin's lymphoma (NHL) $[1,2]$. The 2 most frequent subtypes are diffuse large B-cell lymphoma (DLBCL) and Burkitt lymphoma/leukemia (BL). Both are acquired immune deficiency syndrome (AIDS)-defining illnesses, while Hodgkin's lymphoma (HL) is one of the most common non-AIDS-defining malignancies. As the life expectancy of HIV-positive individuals has increased in the cART era, malignancies have become an important cause of morbidity and mortality. Recent experience indicates that NHL is the most frequent event among all AIDS-related deaths [3].

Overall, patients with ARL can be treated successfully with standard chemotherapy regimens and concomitant cART without outstandingly high rates of toxicity [4]. The exact and accurate determination of disease stage and histological subtype, the performance status, and the recording of comorbidities are essential in finding an individual treatment approach.

\section{Diagnosis and Staging}

Whenever possible, diagnosis should be based on tissue biopsy and not on fine needle aspiration in order to correctly determine the specific lymphoma subtype. The World Health Organization (WHO) has classified ARL into 3 groups: lymphoma occurring in immunocompetent and HIV-positive patients; lymphoma occurring more specifically in HIV-positive patients; and lymphoma occurring in other immunodeficiency states (table 1).

Pretreatment evaluation (table 2) and staging should be performed according to the general recommendations for patients with malignant lymphomas $[5,6]$.

At the time of diagnosis, patients with ARL more often present with an advanced stage, B symptoms, extranodal involvement, and involvement of unusual sites (e.g., soft tissue, body cavity) compared to HIV-negative patients $[7,8]$.

\section{KARGER

(๑) 2017 S. Karger GmbH, Freiburg 
Table 1. WHO classification of lymphoid malignancies associated with human immunodeficiency virus (HIV) infection [58]

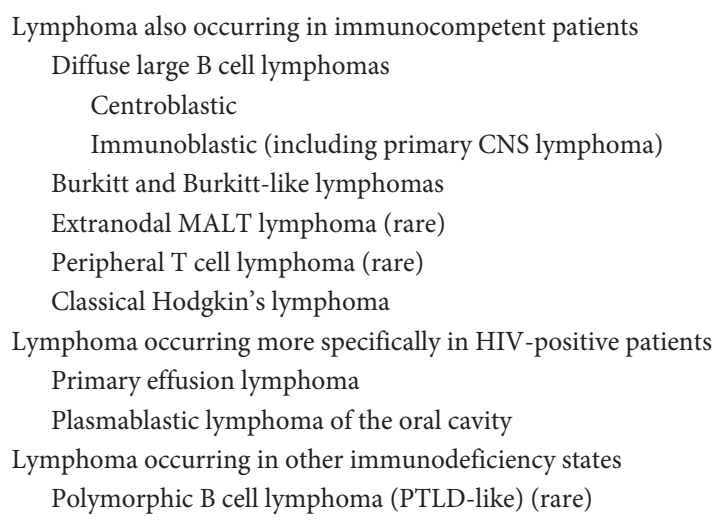

CNS = Central nervous system; MALT = marginal zone lymphoma of mucosaassociated lymphoid tissue; PTLD = posttransplant lymphoproliferative disorder.

Table 2. Pretreatment evaluation/baseline investigations

\section{Medical history}

Physical examination

Blood count with differential, chemistries with electrolytes, liver and renal function, lactate dehydrogenase, urate, phosphate, C-reactive protein, immunoglobulins, serum protein electrophoresis, CD4 count, viral load, hepatitis $\mathrm{B}$ and $\mathrm{C}$ screening, pregnancy test in women

Computed tomography scan of the neck, chest, abdomen, and pelvis with contrast, ideally combined with positron emission tomography scan

Unilateral bone marrow biopsy

Electrocardiogram, echocardiography

Magnetic resonance imaging of the brain and spine if indicated

Cerebrospinal fluid examination if indicated

Upper and lower endoscopy if indicated

\section{Chemotherapy and cART}

The optimal initial therapy for ARL has not been clearly defined yet. The appropriate treatment regimen is determined by stage, performance status, comorbidities, and histological subtype, similar to HIV-negative lymphoma patients.

Current guidelines suggest that antiretroviral therapy should be initiated as soon as possible, irrespective of the CD4 cell count [9]. Delayed introduction of cART has been shown to significantly increase the risk of developing ARL [10]. Furthermore, a significant improvement in complete remission (CR) rates and survival for all patients with ARL receiving cART has been demonstrated [11].

There should be no restrictions for the prompt use of cART. The use of integrase inhibitors bears advantages concerning drugdrug interactions and confers a faster decline of the viremia. By contrast, CYP3A4 inhibitors such as ritonavir and cobicistat-containing regimens should be avoided wherever possible to prevent severe adverse effects $[12,13]$.

\section{Prophylaxis against Opportunistic Infections}

Cotrimoxazole prophylaxis against pneumocystis jiroveci pneumonia and toxoplasmosis should be administered during immunosuppressive treatment with chemotherapy or biological agents such as rituximab regardless of the CD4 cell count [9].

\section{Diffuse Large B-Cell Lymphoma}

DLBCL is the most common subtype of HIV-related lymphomas. It accounts for approximately $45 \%$ of all ARL [14].

R-CHOP (rituximab, cyclophosphamide, doxorubicin, vincristine, oral prednisone) is the most frequently used chemotherapy regimen for the treatment of HIV-related DLBCL. The only randomized phase III trial comparing CHOP versus R-CHOP conducted in the CART era showed an increased death rate from infectious complications, especially in patients with a CD4 count below 50 cells $/ \mu$ l and in those who received rituximab maintenance therapy which is not standard treatment for aggressive lymphomas [15]. However, a number of subsequent prospective clinical studies along with a pooled analysis of 1,546 patients demonstrated that the addition of rituximab to the $\mathrm{CHOP}$ regimen was beneficial and did not lead to a higher rate of death from infectious complications [16-19].

CR rates for R-CHOP immunochemotherapy range between 58 and $77 \%$ [15-17]. In the German AIDS-Related Lymphoma Cohort Study, the 2-year overall survival (OS) was reported to be $63 \%$ [14].

Dose-adjusted (DA) R-EPOCH (rituximab, etoposide, vincristine, oral prednisone, and bolus dose-escalated cyclophosphamide) with continuous infusion over 96-h showed high CR rates of 71 and $91 \%$, respectively, in 2 phase II trials treating HIV-related DLBCL patients [20, 21]. However, a randomized prospective trial in HIV-negative DLBCL showed DA-R-EPOCH and R-CHOP to be equally effective [22]. Nevertheless, R-EPOCH seems to be a reasonable alternative to $\mathrm{R}-\mathrm{CHOP}$.

A central nervous system (CNS)-directed diagnostic work up may be performed according to the CNS International Prognostic Index (CNS-IPI) established for HIV-negative DLBCL [23]. As there is no conclusive data on CNS prophylaxis in HIV-related DLBCL, intrathecal or intravenous methotrexate should be given to prevent secondary CNS manifestation following the same criteria as in HIV-negative patients.

In summary, HIV-positive patients with DLBCL should be treated with rituximab-containing chemotherapy. Special care must be taken in patients with a CD 4 count below 50 cells $/ \mu$, and these patients need appropriate antimicrobial prophylaxis, granulocyte-colony stimulating factor support, and prompt treatment of opportunistic infections. 6-8 cycles of R-CHOP are standard of care [24]. In Germany, a prospective trial evaluating the role of RCHOEP in DLBCL is in preparation. 


\section{Burkitt Lymphoma/Leukemia}

Patients with BL respond poorly to moderate chemotherapy regimens like CHOP [25]. In addition, up to $30 \%$ of BL patients (regardless of HIV status) will develop CNS involvement [26]. HIV-negative patients with $\mathrm{BL}$ are mostly treated with dose-intensive combination chemotherapy containing rituximab and CNS prophylaxis. In Germany, the vast majority of BL patients receive the B-cell acute lymphoblastic leukemia (B-ALL)/NHL protocol of the German Multicenter Study Group for the Treatment of Adult Acute Lymphoblastic Leukemia (GMALL). This regimen is also feasible and effective in HIVpositive BL patients, resulting in a CR rate of $80 \%$ and a 4 -year OS of $72 \%$ [21]. However, toxicity is high with $11 \%$ of deaths upon induction reported in 2 cohorts involving a total of 81 patients [27].

Other dose-intensive regimens like CODOX-M/IVAC (cyclophosphamide, doxorubicin, vincristine, methotrexate, etoposide, ifosfamide, cytarabine) or HyperCVAD/HD-MTX (hyperfractionated cyclophosphamide, vincristine, doxorubicin, and dexamethasone followed by high-dose methotrexate) in combination with rituximab show similar results with CR rates between 63 and $93 \%$ [28-30].

Alternatively, R-EPOCH may be considered for HIV-positive patients with $\mathrm{BL}$, but so far there is only very limited (although promising) data with this approach in the setting of HIV [20] and further studies are required before recommendations regarding its use in this entity can be made. Therefore, patients with HIV-related BL should be treated with intensive regimens such as the B-ALL/NHL 2002 protocol (including CNS prophylaxis and rituximab), provided the patient's performance status allows for such intensive treatment.

\section{Plasmablastic Lymphoma}

Plasmablastic lymphoma (PBL) has been estimated to account for less than 3-12\% of all HIV-related lymphomas [14, 31] featuring a lack of CD20 expression and generally high expression of CD138, a well-differentiated plasma cell marker [32]. Due to its very aggressive clinical course and the disappointing outcome with $\mathrm{CHOP}$ or CHOP-like regimens, more intensive chemotherapy protocols have been suggested such as the B-ALL/NHL protocol, CODOX-M/ IVAC, or consolidation with high-dose (HD) chemotherapy and subsequent autologous stem cell transplantation (SCT). However, the results did not show superior outcomes [33-35], while early clinical stage and complete response to chemotherapy were associated with a better outcome [34]. Bortezomib alone or in combination with chemotherapy has been used with some efficacy in HIV-related PBL [36]. The best approach to therapy still remains unclear.

\section{Primary Effusion Lymphoma}

This very rare entity is associated with a poor prognosis, even in the cART era, with a median OS in the range of 6-10 months [37,
38]. No randomized trials exist. If possible, patients with primary effusion lymphoma (PEL) should be entered into clinical trials with novel treatment approaches like bortezomib [39] or other targeted therapies because of the disappointing results of 'standard' treatment with CHOP or CHOP-like regimens [40].

\section{Treatment of Relapsed or Refractory Systemic HIV- Related NHL}

Before the introduction of cART, treatment of patients with relapsed or refractory ARL was disappointing with a median survival of only a few months. However, with the continuous improvement in immune recovery, several clinical trials have shown that intensive salvage regimens followed by HD chemotherapy and autologous SCT are feasible and effective in chemotherapy-sensitive relapsed or refractory ARL $[41,42]$. A recent large series by the European Society for Blood and Marrow Transplantation (EBMT) suggested that in the cART/chemoimmunotherapy era, the variables that impact the prognosis of autologous SCT for ARL are related to the characteristics of the lymphoma and pretreatment rather than to HIV characteristics [43].

Platinum-based regimens such as ICE (ifosfamide, carboplatin, etoposide) or DHAP (cisplatin, HD cytarabine, dexamethasone) as used in HIV-negative patients are common second-line regimens, usually combined with rituximab, leading to response rates of about $60 \%$ [44].

Allogeneic SCT has been performed in selected cases of relapsed HIV-related lymphoma treated in the cART era [45-47]. Both, reduced intensity conditioning and myeloablative conditioning proved feasible. However, given the limited amount of experience and the lack of long-term efficacy data, no firm conclusions can be drawn. The results of a phase II multicenter trial will provide further insight into the feasibility and safety of allogeneic SCT for HIV-infected patients with chemotherapy-sensitive hematological malignancies (clinicaltrials.gov/ct2/show/NCT01410344).

Brentuximab vedotin has been successfully used in a patient with HIV infection and relapsed anaplastic large cell lymphoma [48].

\section{Primary CNS Lymphoma}

Since the introduction of cART, the incidence of HIV-associated primary CNS lymphoma (PCNSL) has decreased significantly. The OS among AIDS-related PCNSL patients has improved over time but remains poor [49], and no prospective trials are available.

In HIV-negative patients with PCNSL, the treatment of choice are protocols containing HD methotrexate and HD cytarabine in combination with rituximab. This approach may now be offered to the majority of HIV-positive patients, in particular those with a well-controlled HIV viral load and good performance status. If treatment is well tolerated and treatment response is documented, consolidation with HD chemotherapy and subsequent autologous SCT may be considered $[50,51]$. 
Table 3. German Hodgkin's Lymphoma Study Group (GHSG) risk factors defining treatment groups in Hodgkin's lymphoma (adapted from [59])

\section{Early stage}

CS I-II without risk factors

Early unfavorable stage

CS I, CS IIA with $\geq 1$ risk factor; CS IIB with risk factors C/D but no A/B

Advanced stage

CS IIB with risk factors A/B, CS III-IV

Risk factors: large mediastinal mass (A), extranodal disease (B), elevated erythrocyte sedimentation rate $(C), \geq 3$ nodal sites $(D)$

$\mathrm{CS}=$ Clinical stage .

Monotherapy with CNS-penetrating agents like HD methotrexate combined with radiotherapy or whole-brain radiotherapy alone are generally well tolerated palliative approaches and can be useful in reducing symptoms [52].

\section{Hodgkin's Lymphoma}

As in most ARL, HIV-positive patients with HL showed poor outcomes and treatment was associated with significant toxicity before the introduction of cART [53]. However, current data from prospective and retrospective trials have shown promising results. In the prospective German multicenter study using a stage-adapted treatment approach, CR rates were $96 \%$ for early-stage favorable, $100 \%$ for early-stage unfavorable, and $86 \%$ for advanced-stage HL [54]. 2 comparative studies on ABVD (adriamycin, bleomycin, vinblastine, dacarbazine) in HL showed that HIV infection did not adversely affect progression-free and event-free survival or OS [41,
55]. In 1 of the studies in patients with HIV-related HL, most of them with stage III/IV disease, 4-6 cycles of ABVD led to a CR rate of $74 \%$ with a 5 -year OS of $81 \%$ [56].

Treatment of HIV-positive HL patients should be stage-adapted (table 3). Patients with early favorable disease should receive 2 cycles of ABVD with subsequent 20-Gy involved-field radiotherapy. 4 cycles of ABVD followed by $30-G y$ involved-field radiotherapy is the treatment of choice for patients with early unfavorable disease, and patients with advanced stage should receive 6 cycles of BEACOPP baseline (bleomycin, etoposide, adriamycin, cyclophosphamide, vincristine, procarbazine, prednisolone) or 6-8 cycles of ABVD [54].

While no data are currently available on the use of PD1 inhibitors in HIV-related HL, brentuximab vedotin proved effective in a patient with relapsed HL [48]. The combination of brentuximab vedotin and AVD (adriamycin, vinblastine, dacarbazine) is currently being investigated in the upfront treatment of advanced-stage HIVrelated HL (clinicaltrials.gov/ct2/show/NCT01771107) [57].

In conclusion, there is a large body of evidence that HIV-infected individuals who are treated with standard therapies and cART for DLBCL, BL, and HL now have an outcome similar to that of their uninfected counterparts. However, optimal therapies for entities such as PBL, PEL, or high-risk DLBCL have yet to be defined.

\section{Disclosure Statement}

Timo Wolf received fees for lectures and travel grants from Merck Sharp Dome, Gilead, Janssen, and Abbvie. The other authors declare that there is no conflict of interest related to this article.

\section{References}

1 Biggar RJ, Rosenberg PS, Cote T: Kaposi's sarcoma and non-Hodgkin's lymphoma following the diagnosis of AIDS. Multistate AIDS/Cancer Match Study Group. Int J Cancer 1996;68:754-758.

2 Engels EA, Biggar RJ, Hall HI, Cross H, Crutchfield A, Finch JL, Grigg R, Hylton T, Pawlish KS, McNeel TS, Goedert JJ: Cancer risk in people infected with human immunodeficiency virus in the United States. Int J Cancer 2008;123:187-194

3 Lewden C, May T, Rosenthal E, Burty C, Bonnet F, Costagliola D, Jougla E, Semaille C, Morlat P, Salmon D, Cacoub P, Chene G; ANRS EN19 Mortalité Study Group and Mortavic1: Changes in causes of death among adults infected by HIV between 2000 and 2005: the 'Mortalite 2000 and 2005' surveys (ANRS EN19 and Mortavic). J Acquir Immune Defic Syndr 2008;48: 590-598.

4 Mounier N, Spina M, Gisselbrecht C: Modern management of non-Hodgkin lymphoma in HIV-infected patients. Br J Haematol 2007;136:685-698.

5 Lister TA, Crowther D, Sutcliffe SB, Glatstein E, Canellos GP, Young RC, Rosenberg SA, Coltman CA, Tubiana $\mathrm{M}$ : Report of a committee convened to discuss the evaluation and staging of patients with Hodgkin's disease: Cotswolds meeting. J Clin Oncol 1989;7:16301636.
6 Cheson BD, Fisher RI, Barrington SF, Cavalli F, Schwartz LH, Zucca E, Lister TA: Recommendations for initial evaluation, staging, and response assessment of Hodgkin and non-Hodgkin lymphoma: the Lugano classification. J Clin Oncol 2014;32:3059-3068.

7 Gabarre J, Raphael M, Lepage E, Martin A, Oksenhendler E, Xerri L, Tulliez M, Audouin J, Costello R, Golfier JB, Schlaifer D, Hequet O, Azar N, Katlama C, Gisselbrecht C; Groupe d'Etude des Lymphomes de l'Adulte (GELA): Human immunodeficiency virus-related lymphoma: relation between clinical features and histologic subtypes. Am J Med 2001;111:704-711.

8 Heise W: GI-lymphomas in immunosuppressed patients (organ transplantation; HIV). Best Pract Res Clin Gastroenterol 2010;24:57-69.

9 EACS: European AIDS Clinical Society Guidelines version 8.1, Part V: Opportunistic Infections; October 2016. www.eacsociety.org/files/guidelines_8.1-english.pdf.

10 Lundgren JD, Babiker AG, Gordin F, Emery S, Grund B, Sharma S, Avihingsanon A, Cooper DA, Fatkenheuer G, Llibre JM, Molina JM, Munderi P, Schechter M, Wood R, Klingman KL, Collins S, Lane HC, Phillips AN, Neaton JD; INSIGHT START Study Group: Initiation of antiretroviral therapy in early asymptomatic HIV infection. N Engl J Med 2015;373: 795-807.
11 Barta SK, Samuel MS, Xue X, Wang D, Lee JY, Mounier N, Ribera JM, Spina M, Tirelli U, Weiss R, Galicier L, Boue F, Little RF, Dunleavy K, Wilson WH, Wyen C, Remick SC, Kaplan LD, Ratner L, Noy A, Sparano JA: Changes in the influence of lymphoma- and HIVspecific factors on outcomes in AIDS-related nonHodgkin lymphoma. Ann Oncol 2015;26:958-966.

12 Bower M, McCall-Peat N, Ryan N, Davies L, Young AM, Gupta S, Nelson M, Gazzard B, Stebbing J: Protease inhibitors potentiate chemotherapy-induced neutropenia. Blood 2004;104:2943-2946.

13 Cruciani M, Gatti G, Vaccher E, Di Gennaro G, Cinell R, Bassetti M, Tirelli U, Bassetti D: Pharmacokinetic interaction between chemotherapy for non-Hodgkin's lymphoma and protease inhibitors in HIV-1-infected patients. J Antimicrob Chemother 2005;55:546-549.

14 Schommers P, Hentrich M, Hoffmann C, Gillor D, Zoufaly A, Jensen B, Bogner JR, Thoden J, Wasmuth JC, Wolf T, Oette M, Muller M, Esser S, Vehreschild JJ, Fatkenheuer G, Wyen C: Survival of AIDS-related diffuse large B-cell lymphoma, Burkitt lymphoma, and plasmablastic lymphoma in the German HIV Lymphoma Cohort. Br J Haematol 2015;168:806-810. 
15 Kaplan LD, Lee JY, Ambinder RF, Sparano JA, Cesarman E, Chadburn A, Levine AM, Scadden DT: Rituximab does not improve clinical outcome in a randomized phase 3 trial of $\mathrm{CHOP}$ with or without rituximab in patients with HIV-associated non-Hodgkin lymphoma: AIDS-Malignancies Consortium Trial 010. Blood 2005;106:1538-1543.

16 Boue F, Gabarre J, Gisselbrecht C, Reynes J, Cheret A Bonnet F, Billaud E, Raphael M, Lancar R, Costagliola D: Phase II trial of CHOP plus rituximab in patients with HIV-associated non-Hodgkin's lymphoma. J Clin Oncol 2006;24:4123-4128.

17 Ribera JM, Oriol A, Morgades M, Gonzalez-Barca E Miralles P, Lopez-Guillermo A, Gardella S, Lopez A, Abella E, Garcia M; PETHEMA, GELTAMO, GELCAB and GESIDA Groups: Safety and efficacy of cyclophosphamide, adriamycin, vincristine, prednisone and rituximab in patients with human immunodeficiency virus-associated diffuse large B-cell lymphoma: results of a phase II trial. Br J Haematol 2008;140:411-419.

18 Wyen C, Jensen B, Hentrich M, Siehl J, Sabranski M, Esser S, Gillor D, Muller M, Van Lunzen J, Wolf T, Bogner JR, Wasmuth JC, Christ H, Fatkenheuer G, Hoffmann C: Treatment of AIDS-related lymphomas: rituximab is beneficial even in severely immunosuppressed patients. AIDS 2012;26:457-464.

19 Barta SK, Xue X, Wang D, Tamari R, Lee JY, Mounier N, Kaplan LD, Ribera JM, Spina M, Tirelli U, Weiss R, Galicier L, Boue F, Wilson WH, Wyen C, Oriol A, Navarro JT, Dunleavy K, Little RF, Ratner L, Garcia O, Morgades M, Remick SC, Noy A, Sparano JA: Treatment factors affecting outcomes in HIV-associated non-Hodgkin lymphomas: a pooled analysis of 1,546 patients. Blood 2013;122:3251-3262.

20 Sparano JA, Lee JY, Kaplan LD, Levine AM, Ramos JC, Ambinder RF, Wachsman W, Aboulafia D, Noy A, Henry DH, Von Roenn J, Dezube BJ, Remick SC, Shah MH, Leichman L, Ratner L, Cesarman E, Chadburn A, Mitsuyasu R; AIDS Malignancy Consortium: Rituximab plus concurrent infusional EPOCH chemotherapy is highly effective in HIV-associated B-cell nonHodgkin lymphoma. Blood 2010;115:3008-3016.

21 Dunleavy K, Little RF, Pittaluga S, Grant N, Wayne AS, Carrasquillo JA, Steinberg SM, Yarchoan R, Jaffe ES, Wilson WH: The role of tumor histogenesis, FDG$\mathrm{PET}$, and short-course EPOCH with dose-dense rituximab (SC-EPOCH-RR) in HIV-associated diffuse large B-cell lymphoma. Blood 2010;115:3017-3024.

22 Wilson WH, Sin-Ho J, Pitcher BN, Hsi ED, Friedberg J, Cheson B, Bartlett NL, Smith S, Wagner Johnston N, Kahl BS, Staudt LM, Blum K, Abramson J, Press OW, Fisher RI, Richards KL, Schoder H, Chang JE, Zelenetz $\mathrm{AD}$, Leonard JP: Phase III randomized study of R$\mathrm{CHOP}$ versus DA-EPOCH-R and molecular analysis of untreated diffuse large B-cell lymphoma: CALGB/ Alliance 50303. ASH, 58th Ann Meet \& Exposition, San Diego, CA, 3-6 Dec 2016;abstr 469.

23 Schmitz N, Zeynalova S, Nickelsen M, Kansara R, Villa D, Sehn LH, Glass B, Scott DW, Gascoyne RD, Connors JM, Ziepert M, Pfreundschuh M, Loeffler M, Savage $\mathrm{KJ}$ : CNS international prognostic index: a risk model for CNS relapse in patients with diffuse large Bcell lymphoma treated with R-CHOP. J Clin Oncol 2016;34:3150-3156.

24 Hentrich M, Hoffmann C, Mosthaf F, Muller M, Siehl J, Wyen C, Hensel M; DAGNÄ, DAIG: Therapy of HIVassociated lymphoma-recommendations of the oncology working group of the German Study Group of Physicians in Private Practice Treating HIV-Infected Patients (DAGNÄ), in cooperation with the German AIDS Society (DAIG). Ann Hematol 2014;93:913-921.

25 Bishop PC, Rao VK, Wilson WH: Burkitt's lymphoma: molecular pathogenesis and treatment. Cancer Invest 2000;18:574-583.
26 Levine AM: Challenges in the management of Burkitt's lymphoma. Clin Lymphoma 2002;3(suppl 1):S19-25.

27 Xicoy B, Ribera JM, Muller M, Garcia O, Hoffmann C, Oriol A, Hentrich M, Grande C, Wasmuth JC, Esteve J, van Lunzen J, Del Potro E, Knechten H, Brunet S, Mayr C, Escoda L, Schommers P, Alonso N, Vall-Llovera F, Perez M, Morgades M, Gonzalez J, Fernandez A, Thoden J, Gokbuget N, Hoelzer D, Fatkenheuer G, Wyen C; PETHEMA Group and German HIV Lymphoma Cohort: Dose-intensive chemotherapy including rituximab is highly effective but toxic in human immunodeficiency virus-infected patients with Burkitt lymphoma/leukemia: parallel study of 81 patients. Leuk Lymphoma 2014;55:2341-2348.

28 Cortes J, Thomas D, Rios A, Koller C, O’Brien S, Jeha S, Faderl S, Kantarjian H: Hyperfractionated cyclophosphamide, vincristine, doxorubicin, and dexamethasone and highly active antiretroviral therapy for patients with acquired immunodeficiency syndromerelated Burkitt lymphoma/leukemia. Cancer 2002;94: 1492-1499.

29 Wang ES, Straus DJ, Teruya-Feldstein J, Qin J, Portlock C, Moskowitz C, Goy A, Hedrick E, Zelenetz AD, Noy A: Intensive chemotherapy with cyclophosphamide, doxorubicin, high-dose methotrexate/ifosfamide, etoposide, and high-dose cytarabine (CODOXM/IVAC) for human immunodeficiency virus-associated Burkitt lymphoma. Cancer 2003;98:1196-1205.

30 Barnes JA, Lacasce AS, Feng Y, Toomey CE, Neuberg D, Michaelson JS, Hochberg EP, Abramson JS: Evaluation of the addition of rituximab to CODOX-M/IVAC for Burkitt's lymphoma: a retrospective analysis. Ann Oncol 2011;22:1859-1864.

31 Folk GS, Abbondanzo SL, Childers EL, Foss RD: Plasmablastic lymphoma: a clinicopathologic correlation. Ann Diagn Pathol 2006;10:8-12.

32 Noy A, Lensing SY, Moore PC, Gupta N, Aboulafia D, Ambinder R, Baiocchi R, Dezube BJ, Henry D, Kaplan L, Levine AM, Mitsuyasu R, Ratner L, Reid E, Remick S, Sparano J, Tzachanis D, Wachsman W, Chadburn A: Plasmablastic lymphoma is treatable in the HAART era. A 10 year retrospective by the AIDS Malignancy Consortium. Leuk Lymphoma 2016;57:1731-1734.

33 Castillo JJ, Furman M, Beltran BE, Bibas M, Bower M, Chen W, Diez-Martin JL, Liu JJ, Miranda RN, Montoto S, Nanaji NM, Navarro JT, Seegmiller AC, Vose JM: Human immunodeficiency virus-associated plasmablastic lymphoma: poor prognosis in the era of highly active antiretroviral therapy. Cancer 2012;118: 5270-5277.

34 Castillo JJ, Winer ES, Stachurski D, Perez K, Jabbour M, Milani C, Colvin G, Butera JN: Prognostic factors in chemotherapy-treated patients with HIV-associated plasmablastic lymphoma. Oncologist 2010;15:293-299.

35 Schommers P, Wyen C, Hentrich M, Gillor D, Zoufaly A, Jensen B, Bogner JR, Thoden J, Wasmuth JC, Fatkenheuer G, Hoffmann C: Poor outcome of HIV-infected patients with plasmablastic lymphoma: results from the German AIDS-related lymphoma cohort study. AIDS 2013;27:842-845

36 Castillo JJ, Bibas M, Miranda RN: The biology and treatment of plasmablastic lymphoma. Blood 2015; 125:2323-2330.

37 Boulanger E, Gerard L, Gabarre J, Molina JM, Rapp C, Abino JF, Cadranel J, Chevret S, Oksenhendler E: Prognostic factors and outcome of human herpesvirus 8 -associated primary effusion lymphoma in patients with AIDS. J Clin Oncol 2005;23:4372-4380.

38 Guillet S, Gerard L, Meignin V, Agbalika F, Cuccini W, Denis B, Katlama C, Galicier L, Oksenhendler E: Classic and extracavitary primary effusion lymphoma in 51 HIV-infected patients from a single institution. Am J Hematol 2016;91:233-237.
39 Gupta A, Sen S, Marley E, Chen W, Naina HV: Management and outcomes of $\mathrm{HIV}$-associated primary effusion lymphoma: a single center experience. Clin Lymphoma Myeloma Leuk 2016;16(suppl):S175-180.

40 Leitch HA, Oksenhendler E: HIV-associated primary effusion lymphoma; in Hentrich M, Barta SK (eds): HIV-Associated Hematological Malignancies. Cham, Switzerland, Springer International Publishing, 2016, pp. 83-94.

41 Alvarnas JC, Le Rademacher J, Wang Y, Little RF, Akpek G, Ayala E, Devine S, Baiocchi R, Lozanski G, Kaplan L, Noy A, Popat U, Hsu J, Morris LE Jr, Thompson J, Horowitz MM, Mendizabal A, Levine A, Krishnan A, Forman SJ, Navarro WH, Ambinder R: Autologous hematopoietic cell transplantation for HIV-related lymphoma: results of the BMT CTN 0803/AMC 071 trial. Blood 2016;128:1050-1058.

42 Balsalobre P, Diez-Martin JL, Re A, Michieli M, Ribera JM, Canals C, Rosselet A, Conde E, Varela R, Cwynarski K, Gabriel I, Genet P, Guillerm G, Allione B, Ferrant A, Biron P, Espigado I, Serrano D, Sureda A: Autologous stem-cell transplantation in patients with HIV-related lymphoma. J Clin Oncol 2009;27:21922198.

43 Hübel K, Re A, Boumendil A, Finel H, Hentrich M Michieli M, Kanfer E, Diez-Martin JL, Balsalobre P, Vincent L, Schroyens W, Ribera Santasusana JM, Kröger N, Schiel X, Thomson K, Sierra J, Sousa AB, Montoto S, Dreger P: Autologous stem cell transplantation (autoSCT) for HIV-associated lymphoma in the era of combination antiretroviral therapy (cART): a retrospective analysis of the EBMT Lymphoma Working Party. ASH, 58th Ann Meet \& Exposititon, San Diego, CA, 3-6 Dec 2016;abstr 2257.

44 Bi J, Espina BM, Tulpule A, Boswell W, Levine AM: High-dose cytosine-arabinoside and cisplatin regimens as salvage therapy for refractory or relapsed AIDSrelated non-Hodgkin's lymphoma. J Acquire Immune Defic Syndr 2001;28:416-421.

45 Gupta V, Tomblyn M, Pedersen TL, Atkins HL, Battiwalla M, Gress RE, Pollack MS, Storek J, Thompson JC, Tiberghien P, Young JA, Ribaud P, Horowitz MM, Keating A: Allogeneic hematopoietic cell transplantation in human immunodeficiency virus-positive patients with hematologic disorders: a report from the center for international blood and marrow transplant research. Biol Blood Marrow Transplant 2009;15:864871.

46 Johnston C, Harrington R, Jain R, Schiffer J, Kiem HP, Woolfrey A: Safety and efficacy of combination antiretroviral therapy in human immunodeficiency virus-infected adults undergoing autologous or allogeneic hematopoietic cell transplantation for hematologic malignancies. Biol Blood Marrow Transplant 2016;22:149-156.

47 Bryant A, Milliken S: Successful reduced-intensity conditioning allogeneic HSCT for HIV-related primary effusion lymphoma. Biol Blood Marrow Transplant 2008; 14:601-602.

48 Gandhi M, Petrich A: Brentuximab vedotin in patients with relapsed HIV-related lymphoma. J Natl Compr Canc Netw 2014;12:16-19; quiz 19.

49 Uldrick TS, Pipkin S, Scheer S, Hessol NA: Factors associated with survival among patients with AIDS-related primary central nervous system lymphoma. AIDS 2014;28:397-405.

50 O’Neill A, Mikesch K, Fritsch K, Kasenda B, Banerjee L, Burns F, Zakout G, Johnston R, Illerhaus G, Cwynarski K: Outcomes for HIV-positive patients with primary central nervous system lymphoma after highdose chemotherapy and auto-SCT. Bone Marrow Transpl 2015;50:999-1000. 
51 Bower M, Palfreeman A, Alfa-Wali M, Bunker C, Burns F, Churchill D, Collins S, Cwynarski K, Edwards S, Fields P, Fife K, Gallop-Evans E, Kassam S, Kulasegaram R, Lacey C, Marcus R, Montoto S, Nelson M, Newsom-Davis T, Orkin C, Shaw K, Tenant-Flowers M, Webb A, Westwell S, Williams M; British HIV Association: British HIV Association guidelines for HIV-associated malignancies 2014. HIV Med 2014; 15(suppl 2):1-92.

52 Gonzalez-Aguilar A, Soto-Hernandez JL: The management of primary central nervous system lymphoma related to AIDS in the HAART era. Curr Opin Oncol 2011;23:648-653.

53 Kaplan LD: Management of HIV-associated Hodgkin lymphoma: how far we have come. J Clin Oncol 2012; 30:4056-4058.

54 Hentrich M, Berger M, Wyen C, Siehl J, Rockstroh JK, Muller M, Fatkenheuer G, Seidel E, Nickelsen M, Wolf T, Rieke A, Schurmann D, Schmidmaier R, Planker M, Alt J, Mosthaf F, Engert A, Arasteh K, Hoffmann C: Stage-adapted treatment of HIV-associated Hodgkin lymphoma: results of a prospective multicenter study. J Clin Oncol 2012;30:4117-4123.
55 Besson C, Lancar R, Prevot S, Brice P, Meyohas MC, Marchou B, Gabarre J, Bonnet F, Goujard C, Lambotte O, Boue F, Mounier N, Partisani M, Raffi F, Costello R, Hendel-Chavez H, Algarte-Genin M, Trabelsi S, Marchand L, Raphael M, Taoufik Y, Costagliola D: High risk features contrast with favorable outcomes in HIV-associated Hodgkin lymphoma in the modern cART era, ANRS CO16 LYMPHOVIR Cohort. Clin Infect Dis 2015;61:1469-1475.

56 Montoto S, Shaw K, Okosun J, Gandhi S, Fields P, Wilson A, Shanyinde M, Cwynarski K, Marcus R, de Vos J, Young AM, Tenant-Flowers M, Orkin C, Johnson M, Chilton D, Gribben JG, Bower M: HIV status does not influence outcome in patients with classical Hodgkin lymphoma treated with chemotherapy using doxorubicin, bleomycin, vinblastine, and dacarbazine in the highly active antiretroviral therapy era. J Clin Oncol 2012;30:4111-4116.

57 Rubinstein PG, Moore P, Henry DH, Ratner L, Sharon E, Noy A: AMC-085: a pilot trial of AVD and brentuximab vedotin in the upfront treatment of stage II-IV HIV-associated Hodgkin lymphoma. A trial of the AIDS Malignancy Consortium. Blood, 2015;126:abstr 1526.
58 Raphael M, Said J, Borisch B, Cesarman E, Harris NL: Lymphomas associated with HIV infection; in Swerdlow SH, Campo E, Harris NL, et al. (eds): WHO Classification of Tumours of Haematopoietic and Lymphoid Tissues, 4th ed. Lyon, IARC Press, 2008, pp. 340-342.

59 Engert A, Schiller P, Josting A, Herrmann R, Koch P, Sieber M, Boissevain F, De Wit M, Mezger J, Duhmke E, Willich N, Muller RP, Schmidt BF, Renner H, Muller-Hermelink HK, Pfistner B, Wolf J, Hasenclever D, Loffler M, Diehl V; German Hodgkin's Lymphoma Study Group: Involved-field radiotherapy is equally effective and less toxic compared with extended-field radiotherapy after four cycles of chemotherapy in patients with early-stage unfavorable Hodgkin's lymphoma: results of the HD8 trial of the German Hodgkin's Lymphoma Study Group. J Clin Oncol 2003;21: 3601-3608. 